\title{
Intrarenal Gene Expression of Proinflammatory Chemokines and Cytokines in Chronic Proteinuric Glomerulopathies
}

\author{
I. BRABCOVÁ ${ }^{1}, \mathrm{~K} . \mathrm{KOTSCH}^{3}$, P. HŘIBOVÁ ${ }^{1}, \mathrm{~A}$. LOUŽECKÁ ${ }^{1}$, \\ K. BARTOŠOVÁ ${ }^{2}$, K. HYKLOVÁ ${ }^{1}$, J. LÁCHA ${ }^{1,2}$, H.-D. VOLK ${ }^{3}$, O. VIKLICKÝ ${ }^{1,2}$ \\ Transplant Laboratory ${ }^{1}$, Department of Nephrology ${ }^{2}$, Institute for Clinical and Experimental \\ Medicine, Prague, Czech Republic and Institute of Medical Immunology ${ }^{3}$, Medical University \\ Charité, Humboldt University Berlin, Germany
}

Received January 2, 2006

Accepted March 14, 2006

On-line available March 23, 2006

\begin{abstract}
Summary
Proteinuria has been recently shown to be an independent risk factor for the progression of chronic nephropathies, but the actual mechanisms by which urinary protein load damages renal tissue in humans remain unsolved. Using real-time RT-PCR method we evaluated intrarenal mRNA expression of various cytokines and chemokines in patients with biopsy-proven IgA nephropathy (IgAN, $\mathrm{n}=11)$, membranous nephropathy $(\mathrm{MN}, \mathrm{n}=6)$ and focal and segmental glomerulosclerosis (FSGS, $\mathrm{n}=6$ ) who exhibited proteinuria over $0.5 \mathrm{~g}$ /day. There was a significant positive correlation between the proteinuria extent and the intrarenal RANTES (regulated upon activation normal $\mathrm{T}$ cell expressed and secreted) mRNA expression in patients with IgAN, a similar trend was also observed in patients with MN and FSGS. There were no clear relationships between the proteinuria and intrarenal mRNA expression of tumor necrosis factor $\alpha$, transforming growth factor $\beta 1$ and monocyte chemoattractant peptide-1. There were no differences in the pattern of cytokine mRNA expression between different glomerulopathies. In conclusion, our results support the hypothesis that lymphocytes, macrophages and their products provoke tissue injury in response to proteinuria independently of the nature of renal diseases in man.
\end{abstract}

Key words

Chemokines $\bullet$ Gene expression $\bullet$ Glomerulonephritis $\bullet$ Proteinuria

\section{Introduction}

Chronic glomerulopathies represent an important cause of end-stage renal diseases especially among younger patients. Despite a poor understanding of their pathogenesis, different morphological findings and different treatment modalities, the disease progression shares many similarities. Both hypertension and proteinuria represent the independent risk factors for the progression of the disease (Remuzzi and Bertani 1998, Hirschberg and Wang 2005). There is growing evidence suggesting that proteinuria determines tubular cell injury and activation. As a result of this injury, nuclear factor kappa B (NF- $\mathrm{KB})$ translocates to the nucleus of tubular cells, binds to the specific DNA sequence and enhances gene transcription and generation inflammatory cytokines 
Table 1. Clinical parameters at the time of renal biopsy.

\begin{tabular}{llll}
\hline Nephropathy & IgAN & FSGS & MN \\
\hline$n(M / F)$ & $11(6 / 5)$ & $6(3 / 3)$ & $6(1 / 5)$ \\
Age $($ years $)$ & $40.3[25.2-54.3]$ & $43.6[26.9-62.6]$ & $66[35-76.4]$ \\
BMI $\left(\mathrm{kg} / \mathrm{m}^{2}\right)$ & $27.9[20.1-40.2]$ & $25.0[18.4-28.0]$ & $24.0[17.5-33.2]$ \\
Total cholesterol $(\mathrm{mmol} / \mathrm{l})$ & $6.4[4.6-7.6]$ & $9.4[6.3-15.0]$ & $8.0[4.88-17.2]$ \\
Serum creatinine $(\mu \mathrm{mol} / \mathrm{l})$ & $145[67-617]$ & $85[58-140]$ & $111.8[60-150]$ \\
Serum albumin $(\mathrm{g} / \mathrm{l})$ & $38.7[31.2-42.1]$ & $31.5[19.3-47.1]$ & $25.4[14-33]$ \\
GFR $(\mathrm{ml} / \mathrm{s})$ & $1.0[0.2-2.8]$ & $1.5[0.7-3.0]$ & $0.9[0.5-2.0]$ \\
Proteinuria $(\mathrm{g} /$ day) & $2.1[0.5-6.0]$ & $5.3[2.1-13.3]$ & $6.5[3.5-3]$ \\
Hypertension $(\%)$ & 54.5 & 33.3 & 66.7 \\
\hline
\end{tabular}

Data are shown as median [minimum-maximum]. GFR - Glomerular filtration rate estimated using the Cockcroft-Gault formula, IgAN IgA nephropathy, FSGS - focal and segmental glomerulosclerosis, MN - membranous nephropathy, BMI - body mass index. Hypertension was defined as the presence of antihypertensive therapy or blood pressure $>140 / 90 \mathrm{~mm} \mathrm{Hg}$ before biopsy was performed.

and chemokines (Mezzano et al. 2001) such as monocyte chemoattractant peptide-1 (MCP-1), regulated upon activation of normal T-cell expressed and secreted (RANTES), and intracellular cell adhesion molecule-1 (ICAM-1) (Schlondorff 1995). Locally secreted immunoregulating chemokines mediate enhanced tissue infiltration with lymphocytes and monocytes and this process seems to influence the disease progression (Ootaka et al. 1995, Watanabe et al. 2001, Ikezumi et al. 2004). Since most studies on this topic come from experimental models and experience in human kidney biopsies has not been published so far, we studied the gene expression of proinflammatory cytokines and chemokines in patients with primary proteinuric glomerulopathies.

\section{Patients and Methods}

\section{Patients}

Experiments were performed on 34 patients who were referred to our center from May 2002 to January 2004 because of proteinuria and in whom renal biopsy proved primary chronic glomerulopathy. Eleven patients suffered from IgAN, six patients from FSGS and six others from MN. Eleven patients had other morphological findings and were not included in the study. Clinical parameters obtained from patients at the time of biopsy are shown in Table 1. All patients gave their written informed consent to participate in the study and the study protocol was approved by the Ethical Committee of the Institute for Clinical and Experimental Medicine in Prague.

\section{Renal biopsy}

All biopsies were performed using a tru-cut needle (Uni-Cut Nadeln, Angiomed) guided by ultrasound (Toshiba, Power Vision 6000). Most of the renal tissue was used for routine histology. Small portions $(\sim 2 \mathrm{~mm})$ of the cortical or juxtamedulary zone of the renal tissue were immediately frozen in liquid nitrogen and stored at $-80{ }^{\circ} \mathrm{C}$. For the analysis, samples with at least one glomerulus were used. Biopsies were performed to evaluate primary diagnosis and the patients were thus not under immunosuppressive therapy at the time of biopsy.

\section{$R N A$ isolation and real-time quantitative $R T-P C R$}

After renal tissue had been homogenized and total RNA extracted using StrataPrep Total RNA Microprep Kit (Stratagene, La Jolla, United States), it was reversely transcribed into complementary DNA (cDNA), as described elsewhere (Platzer et al. 1994). Complementary DNA was amplified by real-time quantitative polymerase chain reaction (PCR) (TaqMan ${ }^{\circledR}$, ABI Prism 5700 Sequence Detection System, Perkin Elmer, Darmstadt, Germany) using fluorogenic probes. Messenger RNA of chemokines (MCP-1, RANTES) and cytokines - tumor necrosis factor $\alpha$ (TNF- $\alpha$ ) and transforming growth factor $\beta 1$ (TGF- $\beta 1$ ) was quantified. The HPRT housekeeping gene (hypoxanthin-guanin-phosphoribosyl-transferase) was used as an internal standard in the comparative threshold cycle method $\left(2^{-\Delta \mathrm{Ct}}\right)$. All investigated mRNAs were measured in duplicates for each sample. All primers and 
A

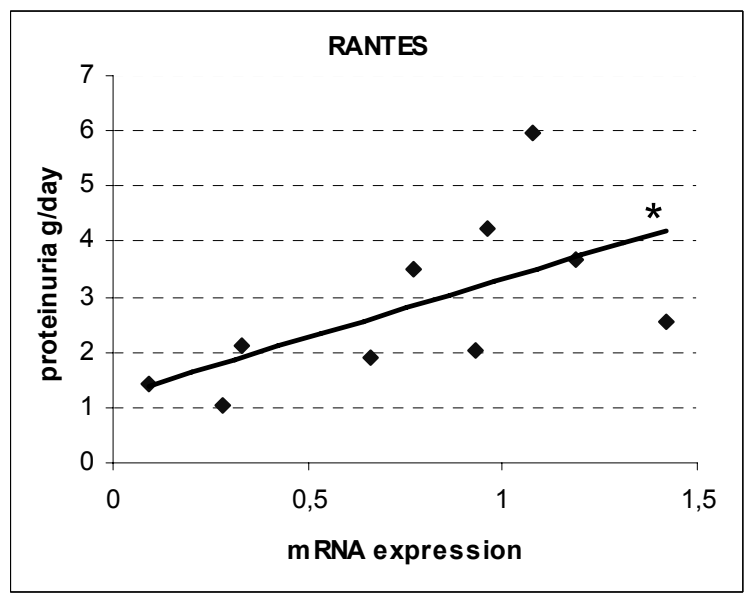

C

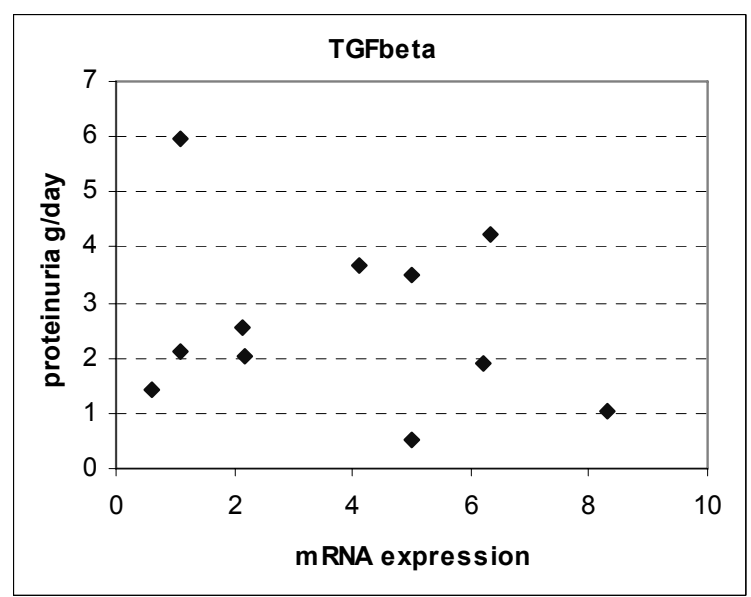

B

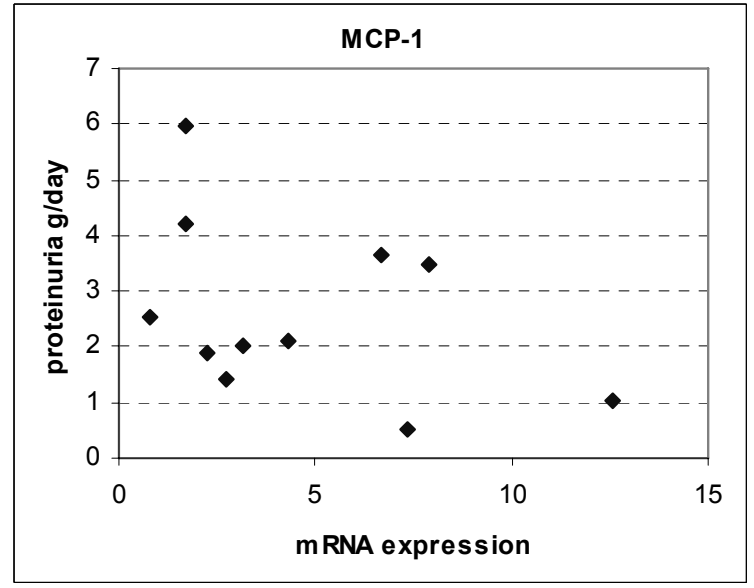

D

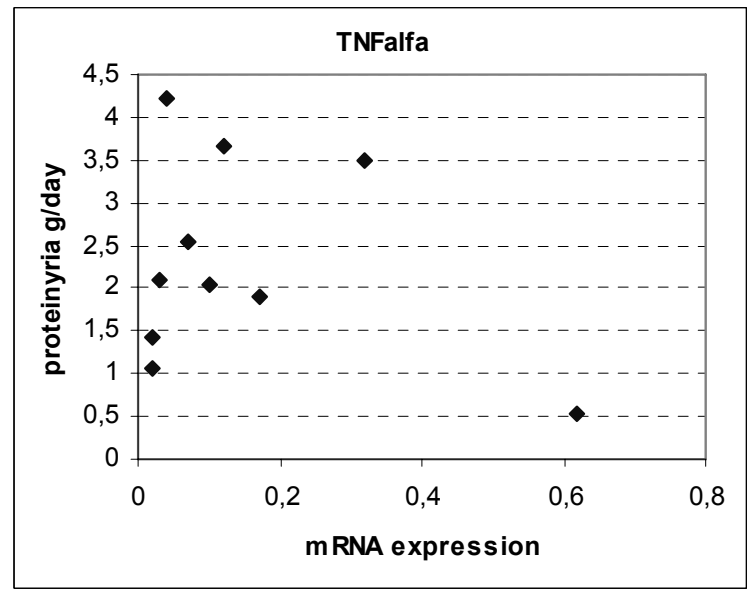

Fig. 1. Correlation between the mRNA expression of cytokine and chemokine genes (normalized to HPRT, $2^{-\triangle C t}$ method) and the proteinuria in patients with proven IgA nephropathy (IgAN). There was a significant relationships between the intrarenal RANTES mRNA expression and the proteinuria (a). ${ }^{*}=p<0.05 ; n=10$. Correlations between MCP-1, TGF- $\beta$ and TNF- $\alpha$ intrarenal gene expressions and proteinuria have not reached statistical significance.

probes were designed, and assays validated at the Institute of Medical Immunology, Universitätsmedizin Charité, Berlin. Because preceding experiments demonstrated amplification efficiencies in our system of nearly 1 for all panels, specific gene expression was calculated relative to that of the housekeeping gene HPRT. Samples were considered negative if the $\mathrm{Ct}$ values exceeded 40 cycles.

\section{Statistical analysis}

Relationship between proteinuria and mRNA expression was assessed using Spearman correlation coefficient calculation. $\mathrm{P}<0.05$ value was accepted to be statistically significant. For the comparison of clinical groups the Kruskal-Wallis test was used.

\section{Results}

In general, the mean age of patients diagnosed with MN was higher than the age of patients with other diagnosis and patients with $\mathrm{MN}$ had higher prevalence of hypertension. Both patient groups, with MN and FSGS, had higher proteinuria and cholesterol plasma levels than patients with IgAN because of the presence of the nephrotic syndrome. The majority of patients had their renal disease in the stage III-IV according K/DOQI classification (Table 1).

In this study, we have shown in patients with IgAN, that RANTES mRNA expression correlated significantly $(\mathrm{p}<0.05)$ with proteinuria (Fig. 1). Similarly, there were trends towards higher RANTES mRNA expression in patients with higher proteinuria who suffered from FSGS and MN, but they did not reach 

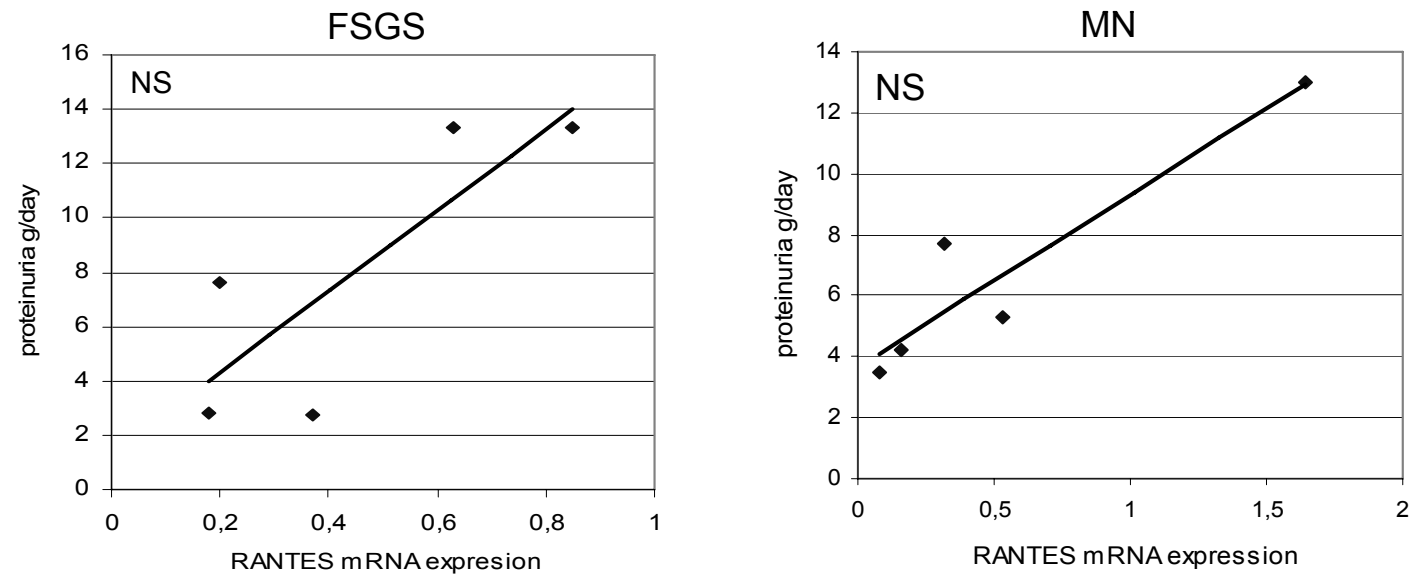

Fig. 2. Relationships between the RANTES mRNA intrarenal expression and the proteinuria level in kidneys with primary focal and segmental glomerulosclerosis (FSGS) and membranous nephropathy (MN).

statistical significance because of the small numbers of patients (Fig. 2). There was no clear relationship between MCP-1, TGF- $\beta 1$, and TNF- $\alpha$ intrarenal mRNA expressions and proteinuria in patients with IgAN, FSGS and MN.

Furthermore, we did not observe significant differences in the pattern of intrarenal mRNA expression of RANTES, MCP-1, TNF- $\alpha$ and TGF- $\beta 1$ among patients who suffered from IgAN, FSGS and MN (Fig. 3).

\section{Discussion}

We demonstrated a positive correlation between the intrarenal gene expression of the chemokine RANTES and proteinuria levels in patients with IgAN. Similarly, there were clear trends towards higher RANTES expression in patients with higher proteinuria who suffered from FSGS and MN. A large variety of injured tubular epithelial cells (Deckers et al. 1998), mesangial cells (Schlondorff et al. 1997), endothelium or stimulated fibroblasts (Rathanaswami et al. 1993) may secrete RANTES. The chemokine RANTES is thought to regulate interstitial inflammation by attracting lymphocytes and macrophages which secrete several profibrogenic regulators including TGF- $\beta 1$, endothelin-1, angiotensin II and plasminogen activator inhibitor-1 (PAI-1) (Hirschberg and Wang 2005). These mediators may act on tubular cells as well as on fibroblasts. In our study, we have not observed any differences of cytokine gene expression among various glomerulonephritis cases. Therefore, there might be no specific correlation between the measured cytokine gene expression and the type of glomerular injury. RANTES may thus play an important role in the progression of glomerular diseases in case of the presence of clinically significant proteinuria.

Surprisingly, we did not observe any differences in MCP-1 gene expression. Mezzano et al. (2004) showed the MCP-1 protein is overexpressed within the tubuli of 11 patients diagnosed with diabetic nephropathy and proteinuria. Our study, however, analyzed the intrarenal MCP-1 gene expression. In this context, it would have been of interest to study MCP-1 also at the protein level. Unfortunately, there is not enough material left from the routine kidney biopsy to perform immunohistological staining. In another study, in situ hybridization revealed the overexpression of MCP-1, at both mRNA and protein levels, in 25 patients with $\mathrm{MN}$ (Mezzano et al. 2000). Thus, we cannot prove these observations in our study, despite the fact that our study included a larger number of subjects.

There were also no differences in either TNF- $\alpha$ or TGF- $\beta 1$ mRNA expression. TNF- $\alpha$ has been observed frequently to be up-regulated during acute inflammatory disorders and also certain experimental therapy in nephrology uses anti-TNF monoclonal antibodies (Zaenker et al. 2004). On the contrary, TGF- $\beta 1$ has been accepted to be associated with fibrogenesis. It seems that there are no relationships between both proinflammatory TNF- $\alpha$ and profibrogenic TGF- $\beta 1$ and proteinuria. Repeated biopsies in the future may elucidate a role of these cytokines in the progression of the disease. Since we had no possibilities to obtain renal biopsy in healthy subjects, we are not able to speculate on the level of cytokine mRNA expression in our patients compared to the normal situation. TGF- $\beta 1$, TNF- $\alpha$, MCP- 1 and RANTES are produced by all types of mononuclear cells, various cell types within the kidney or infiltrating cells. 

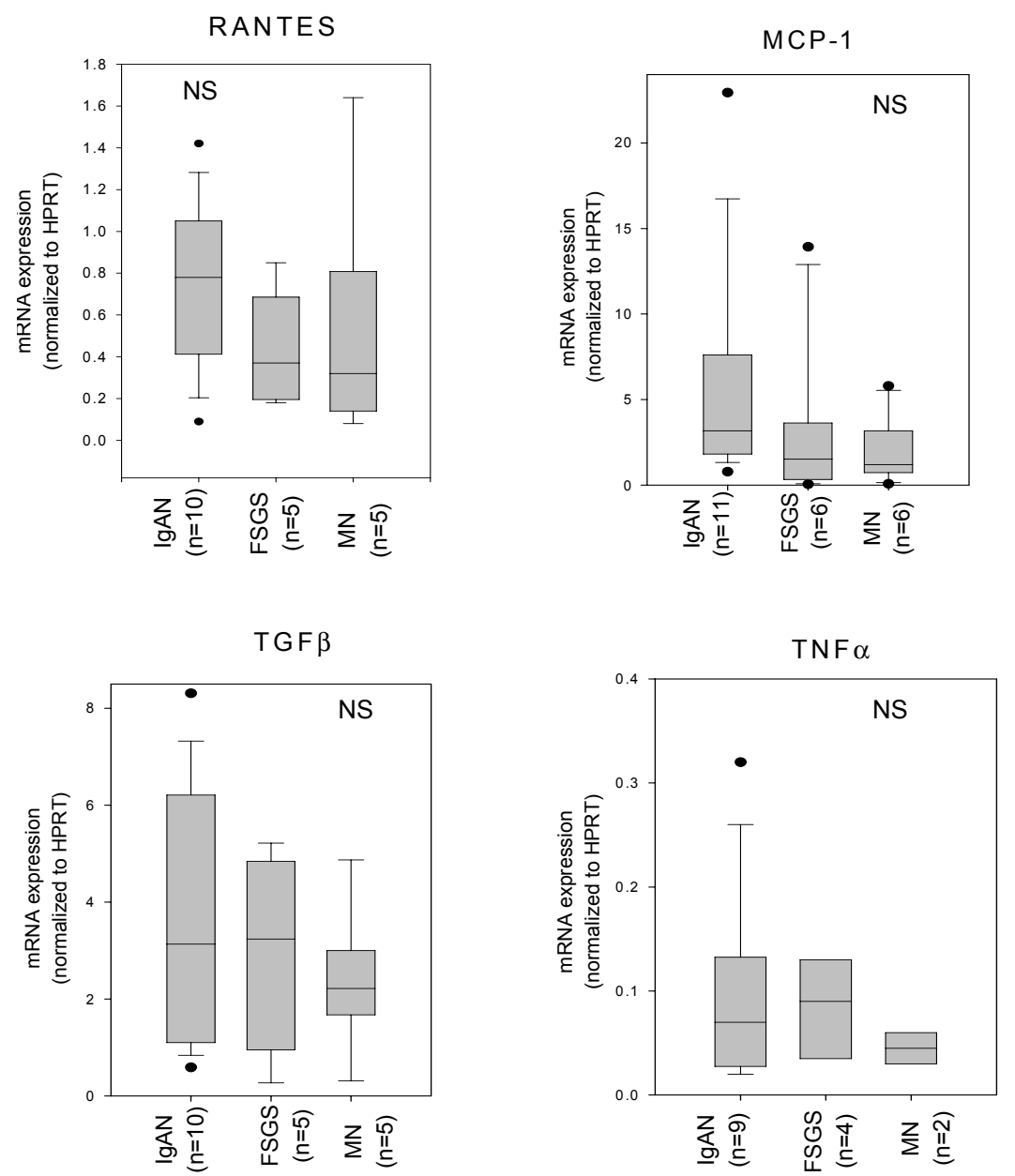

Fig. 3. Quantitative analysis of intrarenal expression of MCP-1, RANTES, TGF- $\beta 1$ and TNF- $\alpha$ mRNA in patients with IgA nephropathy (IgAN), primary focal and segmental glomerulosclerosis (FSGS) and membranous nephropathy (MN). Expression data are normalized to the housekeeping gene HPRT ( $2^{-\Delta C t}$ method). NS: not significant; $n$ : number of patients.

Some studies shows relationships between cytokine expression in peripheral blood mononuclear cells and kidney damage (Yano et al. 1997). Evaluation of cytokine/chemokine mRNA in the urine may provide additional information, however, renal biopsies remain best material reflecting particular changes in the kidney.

Surprisingly, despite small number of patients, our study is one of the largest hitherto published (Segerer et al. 2000, Kim et al. 2001, Lim et al. 2001, 2003). Since biopsy specimens were obtained for just routine morphology, there is not enough material for other immunohistological staining to detect cytokine protein expression within the renal tissue. Similarly, quantitative analysis of infiltrated mononuclear cells may be of interest to draw more definite conclusions. Prospective, costly, and multicenter trials with repeated biopsies may better elucidate the role of the above mentioned cytokines in glomerular proteinuric diseases. Finally, based on our results, it is likely that lymphocytes are involved in the renal injury as a response to proteinuria independently of the nature of renal diseases in man.

\section{Acknowledgements}

We thank J. Skibová for excellent statistical analysis, O. Remeš, M.D. for his help with data collection and T. Dear for English corrections. This work was supported by grant from Ministry of Health, Czech Republic NR/8913-4/2006.

\section{References}

DECKERS JG, VAN DER WOUDE FJ, VAN DER KOOIJ SW, DAHA MR: Synergistic effect of IL-1alpha, IFN-gamma, and TNF-alpha on RANTES production by human renal tubular epithelial cells in vitro. $J$ Am Soc Nephrol 9: 194-202, 1998. 
HIRSCHBERG R, WANG S: Proteinuria and growth factors in the development of tubulointerstitial injury and scarring in kidney disease. Curr Opin Nephrol Hypertens 14: 43-52, 2005.

IKEZUMI Y, KANNO K, KARASAWA T, HAN GD, ITO Y, KOIKE H, TOYABE S, UCHIYAMA M, SHIMIZU F, KAWACHI H: The role of lymphocytes in the experimental progressive glomerulonephritis. Kidney Int 66: 1036-1048, 2004.

KIM YS, ZHENG S, YANG SH, KIM HL, LIM CS, CHAE DW, CHUN R, LEE JS, KIM S: Differential expression of various cytokine and chemokine genes between proliferative and non-proliferative glomerulonephritides. Clin Nephrol 56: 199-206, 2001.

LIM CS, ZHENG S, KIM YS, AHN C, HAN JS, KIM S, LEE JS, CHAE DW, KOO JR, CHUN RW, NOH JW: Th1/Th2 predominance and proinflammatory cytokines determine the clinicopathological severity of IgA nephropathy. Nephrol Dial Transplant 16: 269-275, 2001.

LIM CS, YOON HJ, KIM YS, AHN C, HAN JS, KIM S, LEE JS, LEE HS, CHAE DW: Clinicopathological correlation of intrarenal cytokines and chemokines in IgA nephropathy. Nephrology (Carlton) 8: 21-27, 2003.

MEZZANO SA, DROGUETT MA, BURGOS ME, ARDILES LG, AROS CA, CAORSI I, EGIDO J: Overexpression of chemokines, fibrogenic cytokines, and myofibroblasts in human membranous nephropathy. Kidney Int 57: 147-158, 2000.

MEZZANO SA, BARRIA M, DROGUETT MA, BURGOS ME, ARDILES LG, FLORES C, EGIDO J: Tubular NF- $\kappa \mathrm{B}$ and AP-1 activation in human proteinuric renal disease. Kidney Int 60: 1366-1377, 2001.

MEZZANO S, AROS C, DROGUETT A, BURGOS ME, ARDILES L, FLORES C, SCHNEIDER H, RUIZ-ORTEGA M, EGIDO J: NF- $\mathrm{BB}$ activation and overexpression of regulated genes in human diabetic nephropathy. Nephrol Dial Transplant 19: 2505-2512, 2004.

OOTAKA T, SAITO T, YUSA A, MUNAKETA T, SOMA J, ABE K: Contribution of cellular infiltration to the progression of IgA nephropathy: a longitudinal immunocytochemical study on repeated biopsy specimens. Nephrology 1: 135-142, 1995.

PLATZER C, ODE-HAKIM S, REINKE P, DOCKE WD, EWERT R, VOLK HD: Quantitative PCR analysis of cytokine transcription patterns in peripheral mononuclear cells after anti-CD3 rejection therapy using two novel multispecific competitor fragments. Transplantation 27: 58: 264-268, 1994.

RATHANASWAMI P, HACHICHA M, SADICK M, SCHALL TJ, MCCOLL SR: Expression of the cytokine RANTES in human rheumatoid synovial fibroblasts. Differential regulation of RANTES and interleukin-8 genes by inflammatory cytokines. J Biol Chem 268: 5834-5839, 1993.

REMUZZI G, BERTANI T: Pathophysiology of progressive nephropathies. N Engl J Med 339: 1448-1456, 1998.

SEGERER S, CUI Y, HUDKINS KL, GOODPASTER T, EITNER F, MACK M, SCHLONDORFF D, ALPERS CE: Expression of the chemokine monocyte chemoattractant protein-1 and its receptor chemokine receptor 2 in human crescentic glomerulonephritis. J Am Soc Nephrol 11: 2231-2242, 2000.

SCHLONDORFF D: The role of chemokines in the initiation and progression of renal disease. Kidney Int Suppl 49: S44-S47, 1995.

SCHLONDORFF D, NELSON PJ, LUCKOW B, BANAS B: Chemokines and renal disease. Kidney Int 51: 610-621, 1997.

WATANABE T, KAWACHI H, IKEZUMI Y, YANAGIHARA T, ODA Y, SHIMIZU F: Glomerular CD8+ cells predict progression of IgA nephropathy. Pediatr Nephrol 16: 561-567, 2001.

YANO N, ENDOH M, NOMOTO Y, SAKAI H, FADDEN K, RIFAI A: Phenotypic characterization of cytokine expression in patients with IgA nephropathy. J Clin Immunol 17: 396-403, 1997.

ZAENKER M, ARBACH O, HELMCHEN U, GLORIUS P, LUDEWIG S, BRAASCH E: Crescentic glomerulonephritis associated with myeloperoxidase-antineutrophil-cytoplasmic antibodies: first report on the efficacy of primary anti-TNF-alpha treatment. Int J Tissue React 26: 85-92, 2004.

\section{Corresponding author}

O. Viklický, Department of Nephrology, Transplant Laboratory, Institute for Clinical and Experimental Medicine, Videnska 1958, 14000 Prague 4, Czech Republic. E-mail: ondrej.viklicky@medicon.cz 